\title{
Implementation of Food Safety Traceability Systems in The Product Supply Chain at PT. XYZUsing Quality Function Deployment (QFD)
}

\author{
Syafrilla Dinda Khumairo ${ }^{1}$, Hana Catur Wahyuni ${ }^{2}$ \\ ${ }^{1,2}$ Industrial Engineering Department, Faculty of Sains and Technology \\ University of Muhammadiyah Sidoarjo \\ e-mail : syafrilladinda@umsida.ac.id
}

\begin{abstract}
PT. XYZ is a food manufacturing company with shrimp crackers as its main product. This research aims to analyze and make improvements to the food safety traceability system that has been applied previously and to develop products of PT. XYZ using Quality Function Deployment Method (QFD). This research uses paper-based traceability and Quality Function Deployment Method (QFD).After analyzing the food safety traceability system and analyzing consumer needs using the QFD method, the results of the analysis show that the food safety traceability system is improved by integrating coding along the supply chain and improving documentation. Improvements using QFD method is based on three main priorities, those are maintaining consistency in the aspect of packaging according to prevailing standards, packaging product that is informative, as well as maintaining and improving the aspects of color, taste, and smell of the product.
\end{abstract}

Kata kunci: Supply chain, Traceability, Food safety, QFD.

\section{INTRODUCTION}

PT. XYZ is a food manufacturing companythat produces crackers with flavor variantsserves international markets. PT. $\mathrm{XYZ}$ is improving the overall food safety traceability systembut it's still constrained in the production process, especially after the slicing process. The one of impact before the improvement of traceability system is the lack of integrated supply chain that making it more difficult to detect the risks. This research using traceability method that combined with Quality Function Deploymentmethod(QFD).This method was chosen because it is based on the needs and desires of consumers so that it helps in the process of designing strategies in realizing products that are suitable for the needs of consumers.

In this research, we will explain how the implementation of the food safety traceability system is implemented and efforts in product planning and development at PT. XYZ. The goal of this research is to know the implementation of the food safety system, knowing the parties involved and their role in the food safety traceability system at PT. XYZ,make recommendations on the implementation of the food safety system, and know the priority of technical responses that consumers expect to be realized as an effort to develop products.

Supply Chain Management is an alternative strategy and provides solutions to achieve competitive advantage through improving customer service and customer satisfaction in an uncertain environment. This alternative strategy is a mechanism that regulates starting from business processes, increasing productivity, and minimizing the company's operational costs(Anatan, 2008).

Food safety is the main and very important requirement of all existing food quality parameters. Consumers now realize that food safety in a product cannot be guaranteed only by the product test results in the laboratory. Consumers believe that good products are made of good quality raw materials, good handling, processed and distributed according to standard, so that it will produce a good final product.

The traceability method is structured for the elaboration process and information flow at each step in the food supply chain. This system requires the identification of all physical entities, the origin of the product, to the location where it is processed, packaged and stored. The European 


\section{Tibuana}

Jurnal Teknik Industri Terapan - Universitas PGRI Adi Buana

DOI : https://doi.org/10.36456/tibuana.4.01.3176.36-43

Commission defines the traceability method as the ability to track or trace raw food, feed, foodproducing animals, or substances that will become a mixture or to be mixed into food or feed, through all stages of production, processing and delivery (Tang, 2015).

Guaranteeing the quality of food products, traceability methods combined with the Quality Function Development method (QFD) can help to improve the quality of food safety as well as product development, because the QFD method helps translate consumer desires into technical responses that need to be prioritized (Andayani, 2015).

\section{RESEARCH METHODOLOGY}

Data collection techniques in this study used the method of field studies, interviews, literature studies and questionnaires. While the stages of data processing in this research are traceability in each supply chain flow from receiption of raw materials to the distribution process using paper-based traceability and document records, as well as compiling House of Quality (HOQ) to determine the priority of customer needs and the preparation of appropriate technical responses.

\section{RESULT AND DISCUSSION}

In the supply chain at PT. XYZ has traceability codes, namely the process flow code, machines, work groups, raw materials, suppliers, cracker sizes, product lotS and attributes of voice of customer data collection (see table 1).

Table 1. voice of customer attributes

\begin{tabular}{|c|c|}
\hline Primary & Secondary \\
\hline Taste, Aroma and color & $\begin{array}{l}\text { 1. The color is not pale } \\
\text { 2. The aroma isn't rancid } \\
\text { 3. The taste of the crackers is good } \\
\text { 4. Crackers do not cause stickiness or other irritation when eaten } \\
\text { (aftertaste) } \\
\text { 5. Crispness / Mouthfeel }\end{array}$ \\
\hline Nutritional content & $\begin{array}{l}\text { 1. Ideal fat content } \\
\text { 2. Ideal protein content } \\
\text { 3. Calorie content meets nutritional content } \\
\text { 4. Ideal vitamin content }\end{array}$ \\
\hline Food safety & $\begin{array}{ll}\text { 1. } & \text { Durability } \\
\text { 2. } & \text { Hygenic }\end{array}$ \\
\hline Product Display & $\begin{array}{l}\text { 1. Package arrangement } \\
\text { 2. Intactness of the product in the package } \\
\text { 3. Precision size }\end{array}$ \\
\hline Packaging & $\begin{array}{ll}\text { 1. } & \text { Ingredients } \\
\text { 2. } & \text { Attractive packaging } \\
\text { 3. } & \text { Easy to store } \\
\text { 4. } & \text { The volume is not small } \\
\text { 5. } & \text { Production date } \\
6 . & \text { Halal label } \\
\text { 7. } & \text { Expired date } \\
\text { 8. } & \text { BPOM RI information } \\
\text { 9. } & \text { Easy to open packaging }\end{array}$ \\
\hline
\end{tabular}

The steps to improve implementation of the implemented after the slicing process (see food safety traceability system at PT. XYZ is figure 1). 


\section{Tibuana}

Jurnal Teknik Industri Terapan - Universitas PGRI Adi Buana

DOI : https://doi.org/10.36456/tibuana.4.01.3176.36-43

Figure 1. The Process of Improving the Implementationof Traceability System After Slicing Process

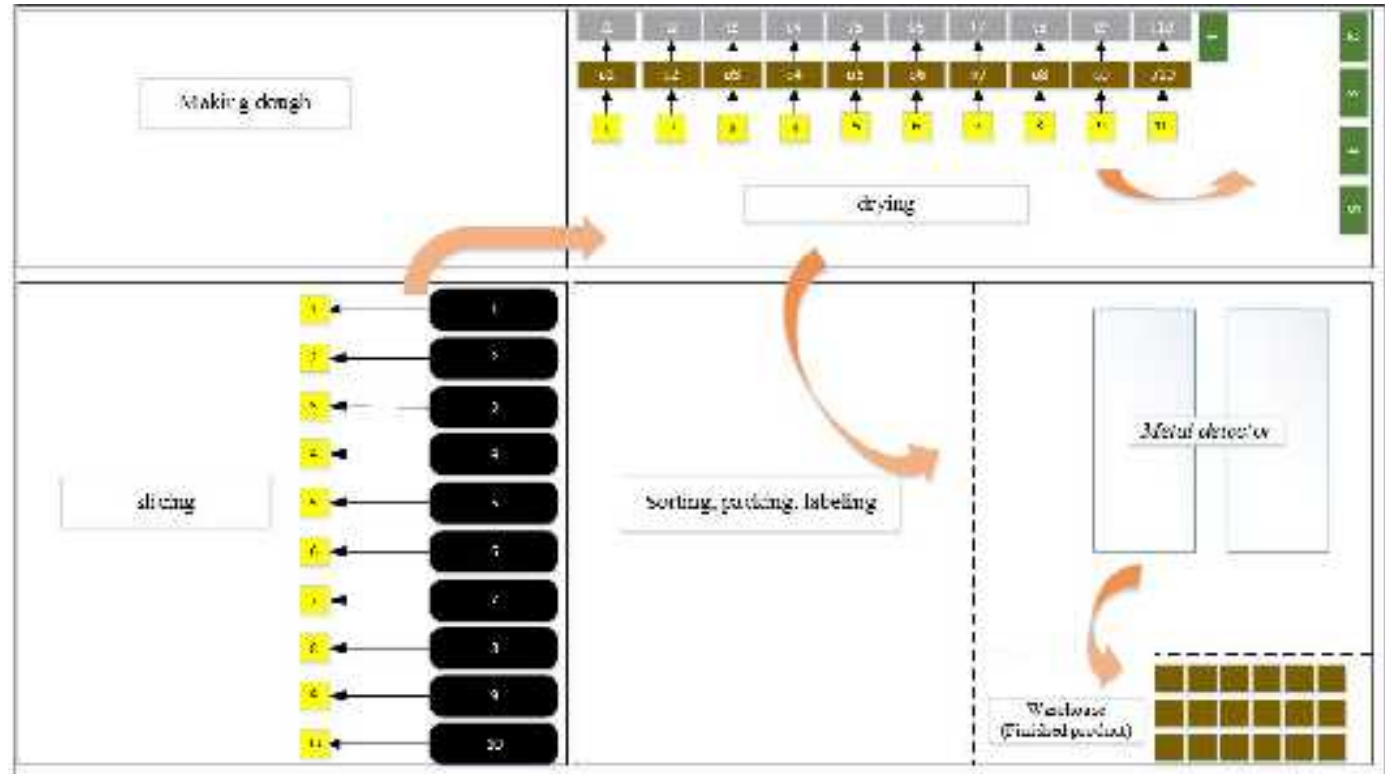

Description diagram:
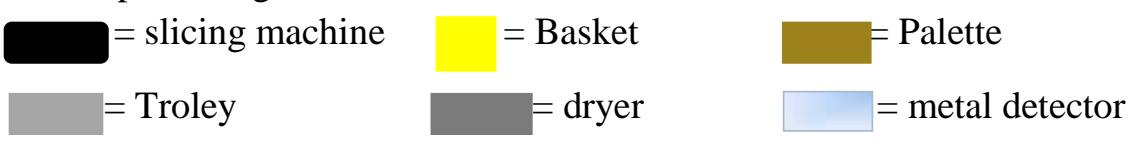

$=$ Finished Product

The following is an explanation of the diagram above:

1. After slicing, the crackers are placed in a basket that matches the machine number (if the machine is 10 then put in basket 10).

2. Damage to slicing machines at PT. XYZ is still quite frequent but the lack of a number of machine operators causes two machines to be operated by one person or one machine operated by two people.Substitution of operators is attempted to always follow the procedures compiled by the QA / QC department.

3. After the crackers are placed in a basket, then the crackers are dried on a pallet that matches the basket code.

4. Dried crackers on the pallet are arranged into trolleys that have production line codes.

5. When drying crackers using a dryer machine, a system of grouping machines is applied (see table

Table 2. Grouping machines

\begin{tabular}{cc}
\hline Production lines & Dryer machines \\
\hline $1-2$ & 1 \\
$3-4$ & 2 \\
$5-6$ & 3 \\
$7-8$ & 4 \\
$9-10$ & 5
\end{tabular}

6. When sorting using a metal detector, $a$ sequence is taken from the results of drying crackers 1 to 10 alternately.

7. Finished products are stacked or grouped according to shipping / export destinations

8. Packing and labeling of lot codes is done after sorting is complete.
9. In each process flow, it is recommended that there be a supervisor to carry out supervision as well as record information, so that the system search can be tracked properly.

10. Documentation to find errors that might occur during the traceability system. 


\section{Tibuana}

Jurnal Teknik Industri Terapan - Universitas PGRI Adi Buana

DOI : https://doi.org/10.36456/tibuana.4.01.3176.36-43

11. Records of information documentation based on traceability components at PT. XYZis carried out based on activities related to each traceability flow, techniques used to compile table / specific information capture point based on process flow from receipt of raw materials to finished products (see table

Table 3. Example ofProperty Table of food safety traceability system at PT. XYZ

\begin{tabular}{|c|c|c|c|c|c|}
\hline & Activity & Information & System & Organization & Description \\
\hline 1 & $\begin{array}{l}\text { Raw Material Receipt } \\
\text { and Check } \\
\text { (S.Pm.Pb.1) }\end{array}$ & $\begin{array}{ll}\text { - } & \text { Supplier Code } \\
\text { - } & \text { Sender's identity } \\
\text { - } & \text { Date and period of } \\
\text { arrival of raw } \\
\text { materials } \\
\text { - } \\
\text { total } \\
\text { - } & \text { Raw material code } \\
\text { - } & \text { Code of recipient } \\
\text { and examiner }\end{array}$ & 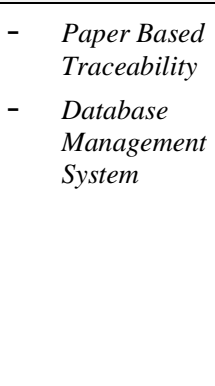 & $\begin{array}{ll} & \text { Supplier } \\
-\quad & \text { Warehouse (Manufacturer) }\end{array}$ & Raw material \\
\hline 2 & $\begin{array}{l}\text { Shrimp mill } \\
\text { (M.Pb.1) }\end{array}$ & $\begin{array}{ll}\text { - } & \text { Processing } \\
\text { (production) date } \\
\text { - } & \text { Raw material code } \\
\text { - } & \text { Tool code } \\
\text { - } & \text { Working group code }\end{array}$ & 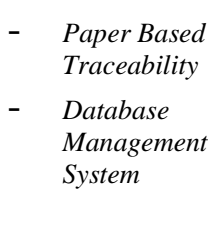 & Production department & $\begin{array}{l}\text { Semi-finished } \\
\text { material }\end{array}$ \\
\hline 3 & $\begin{array}{l}\text { Delivery } \\
(\mathrm{DEPb} .1)\end{array}$ & $\begin{array}{l}\text { - } \begin{array}{c}\text { Date and time of } \\
\text { product delivery }\end{array} \\
\text { - } \quad \text { Expeditor identity } \\
\text { - }\end{array}$ & $\begin{array}{l}\text { - } \quad \text { Paper Based } \\
\text { Traceability } \\
\text { - } \quad \text { Database } \\
\text { Management } \\
\text { System }\end{array}$ & $\begin{array}{l}\text { - Warehouse (manufacturer) } \\
\text { - Expeditor }\end{array}$ & Product \\
\hline
\end{tabular}

The following is an explanation of property table/ specific information capture point:

1. Activity column: this column shows related process activities and special codes. This code consists of letters and numbers. Activities are mapped based on the following aspects::

a. Business process area: Source (S) shows activities related to raw materials or other activities related to the warehouse area, Make (M) shows activities related to the production or manufacturing of products, and Deliver (D) relates to finished product storage activites until delivery.

b. Supply chain actors: supply chain actors are symbolized by $\mathrm{Pm}, \mathrm{Pb}$, and $\mathrm{E}$. Pm (supplier) is the code for raw material suppliers, $\mathrm{Pb}$ (Factory) is a code for manufacturers, while E (Expeditor) is for third parties who deliver finished products to the buyer.

c. Number: numeric code shows the sequence of process flow.

2. Information column: this column shows information based on the traceability component in each process flow. This information is a collection of data / database to find out the details of each process flow code.

3. System column: this column shows information about the techniques applied in helping to the implementation of traceability system.

4. Organizational column: this column shows information about the parties involved in each process flow.

5. Search column: this column shows information about objects involved in each process flow.

After implementing food safety traceability, it is necessary to prioritize improvement and development analysis using the Quality Function Deploymentmethod(QFD) that requires data from 56 respondents through a questionnaire. The following are the stages of preparing the House of Quality (HOQ):

1. Determine customer needs (WHATS)

2. Determine Technical Responses ( HOWS )

3. Translation of customer needs into technical responses.

4. Determining Customer Needs and Relationship Technical Responses (see picture 2) 


\section{Tibuana}

Jurnal Teknik Industri Terapan - Universitas PGRI Adi Buana

DOI : https://doi.org/10.36456/tibuana.4.01.3176.36-43

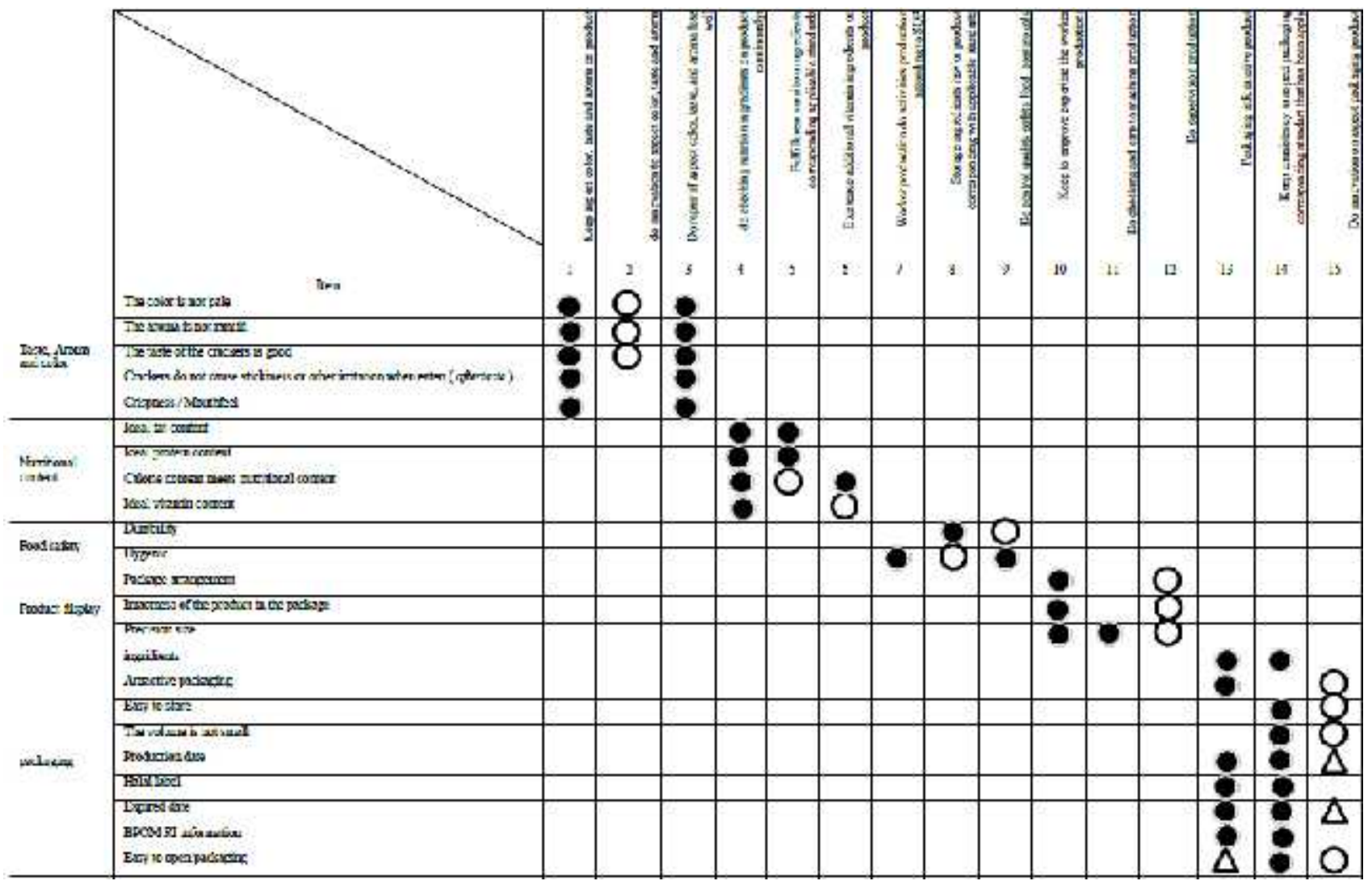

Figure 2. Customer need and technical response relationship

5. Determine the Relationship of the Technical

Response Matrix (Technical Correlation) (see figure 3).

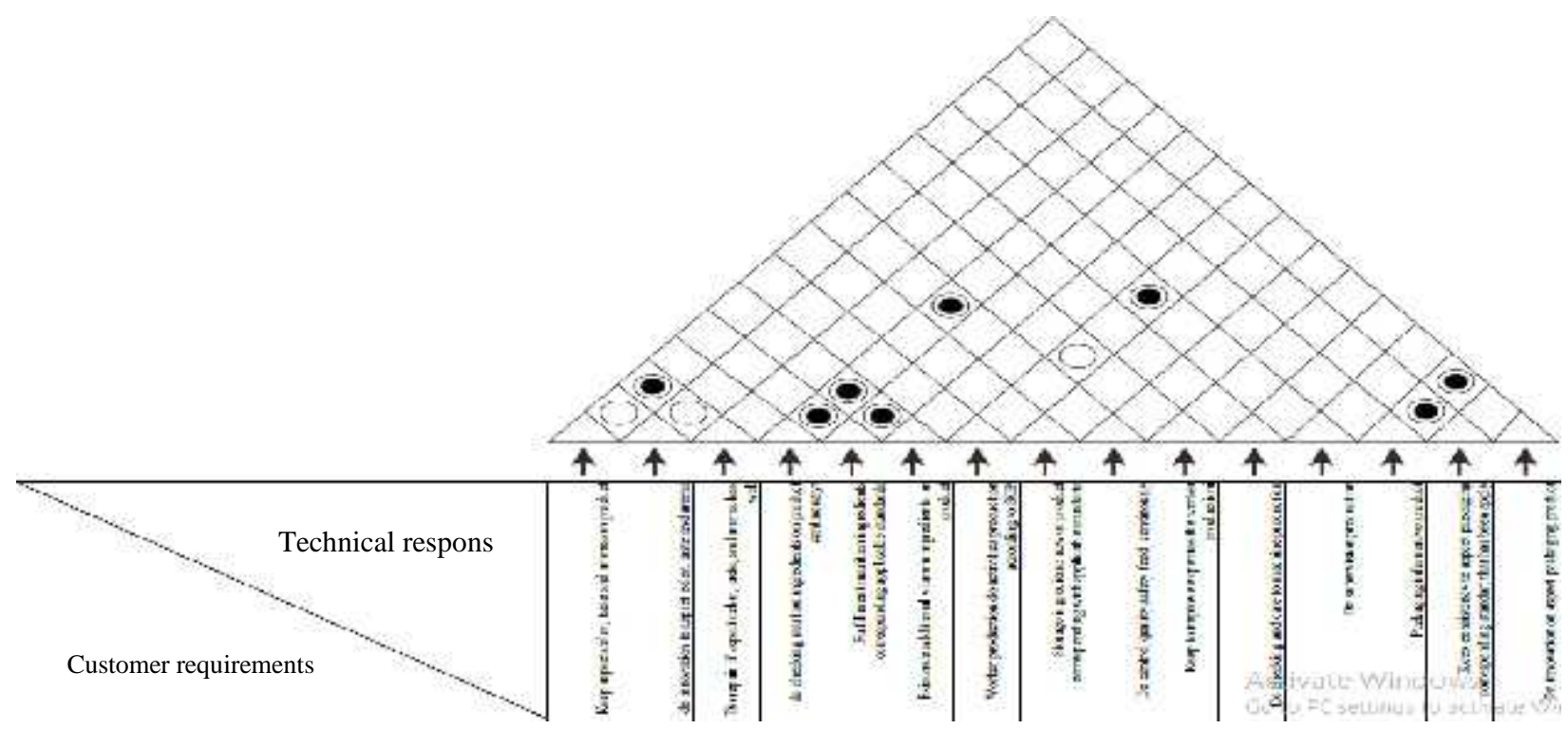

Figure 3. Technical Correlation 


\section{Tibuana}

Jurnal Teknik Industri Terapan - Universitas PGRI Adi Buana

DOI : https://doi.org/10.36456/tibuana.4.01.3176.36-43

6. Determine the planning and technical matrix, which consists of stages as follows:

a. Calculate the Importance to Customer of each Customer needs. With the formula:

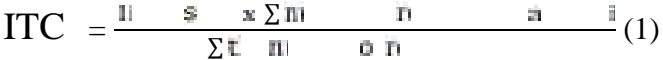

$$
\begin{aligned}
& \mathrm{ITC}=\frac{(1 \times \mathrm{u})+(2 \times \mathrm{u})+(3 \times 3)+(4 \times 1)}{5} \\
& =\frac{1}{5}=3,34
\end{aligned}
$$

b. Calculate customer satisfaction performance perceived and expected from each customer needs:

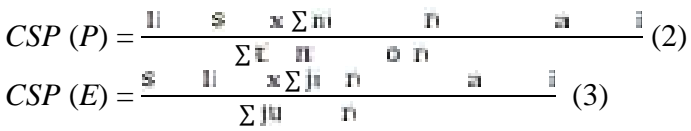

c. Calculate the difference (gap) between customer satisfaction performance perceived and expected.

d. Calculate the goals for each customer needs, using the following formula:

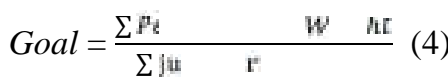

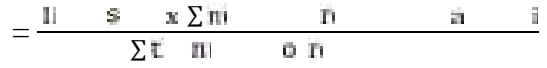

e. Calculate the Improvement Ratio for each customer needs, using the following formula:

$\mathrm{IR}=\frac{\mathrm{G}}{C \quad(\mathrm{P} \quad)}(5)$

f. Determine the sales point value for each customer needs:

- $\quad 1=$ no selling point

- $\quad 1.2$ = medium selling point

- $\quad 1,5=$ strong selling point

g. Calculates the raw weight for each customer needs using the following formula:

$\mathrm{RW}=(\mathrm{ITC}) \times(\mathrm{IR}) \times(\mathrm{SP})(6)$

h. Calculates raw weight normalized, using the following formula:

$\mathrm{NRW}=\frac{R_{i} \quad W \quad h L}{T \quad R_{i} \quad W \quad h L}(7)$

i. Calculate contribution and Normalized contribution from each cutomer needs, using the following formula:
$C=\sum[(N i \quad) x(m i$
$\left.\begin{array}{ll}v & )\end{array}\right](8)$
$\mathrm{NC}=\frac{c}{T}$

\begin{tabular}{|c|c|c|c|c|c|c|c|c|}
\hline \multirow{2}{*}{$\begin{array}{l}\text { Ineportance } \\
\text { custamer } \\
\text { Custam }\end{array}$} & \multicolumn{3}{|c|}{ 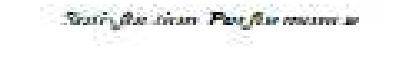 } & \multirow{2}{*}{ Anesit } & \multirow{2}{*}{ 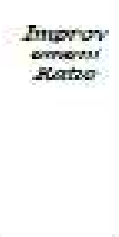 } & \multirow{2}{*}{$\begin{array}{l}\text { Salers } \\
\text { Pother }\end{array}$} & \multirow{2}{*}{$\frac{\text { Ranv }}{\text { Wratgir }}$} & \multirow{2}{*}{$\begin{array}{l}\text { Normanized } \\
\text { Row watghr }\end{array}$} \\
\hline & Percenved & Expectind & Gap: & & & & & \\
\hline 3,31 & 3,5 & 5,90 & 0,10 & 3,90 & 1,13 & 1,2 & 4,35 & 0,01 \\
\hline 7,3 & 3.32 & 7.03 & $-\Omega, 61$ & 7.07 & 1.18 & 1,2 & 4.67 & 0.041 \\
\hline 3,11 & 3,11 & 3,68 & $-0,57$ & 3,08 & 1.18 & 1,5 & 5,5 & 0,048 \\
\hline 7.21 & $7 x 3$ & 9.79 & $\Omega s$ & 3.73 & 1.17 & 15 & $8: 34$ & an4o \\
\hline 3,34 & 3.36 & 3,77 & 0,41 & 3,77 & 1.12 & 1,5 & 5,61 & $0,0-19$ \\
\hline 7,11 & 9.8 & 3.71 & $-0,2,1$ & 7.71 & $1 \mathrm{~ns}$ & 1,2 & 706 & 0.075 \\
\hline 3,15 & 5,312 & 5,01 & 0.23 & 5,01 & 1,00 & 1,2 & $\pi, 30$ & ousts \\
\hline 3,30 & 3,31 & 3,32 & 0,18 & 4,52 & 1,02 & 1,3 & 3,20 & e,orl \\
\hline 7,27 & 3.25 & 3.52 & $-0,37$ & 7.52 & $1 \Omega$ & 1,2 & 4,21 & $0.0 * 7$ \\
\hline 3.01 & $5,0 \mathrm{~s}$ & $5, \infty 0$ & 0.21 & 4.89 & 1,00 & 1,0 & 3,19 & ous 1 \\
\hline 3.5 & 3.52 & 3.96 & -0.34 & 3.06 & 1.1 & 1.5 & 5.75 & 0.051 \\
\hline 7.2 & $3 . x 7$ & 3.57 & -0.34 & 7.57 & 1.11 & 1,2 & 4,36 & 0,078 \\
\hline 3,41 & $5,4 s$ & 5,73 & $-0,5$ & $5,1 / 5$ & 1,00 & 1,1 & 4,40 & ousts \\
\hline 3.38 & 3.36 & 3.59 & -0.23 & 3.59 & 1.07 & 1.2 & 4.34 & 0.030 \\
\hline 3.55 & 3,01 & 3,77 & $-0,16$ & 3,77 & 1.04 & 1,5 & 5,54 & 0,040 \\
\hline 3,43 & 3,45 & 3,7 & $-0,25$ & 3.7 & 1,07 & 1,5 & 5.51 & 0,048 \\
\hline 3.32 & 3.40 & 3.66 & -0.10 & 3.66 & 1.05 & 1.2 & 4.18 & 0.037 \\
\hline 3.31 & 3,3 & 3,04 & $-0,34$ & 3,64 & 1,1 & 2,2 & 4,38 & 0,038 \\
\hline 3,40 & 3,48 & 3,82 & $-0,34$ & 3,82 & 1,1 & 1,2 & 4,57 & 0,04 \\
\hline 3.18 & 3.41 & 3.04 & -0.43 & 3.04 & 1.13 & 1.5 & 5.39 & 0.047 \\
\hline 7.34 & 9.74 & 9.84 & -0.5 & 7,84 & 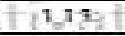 & $2 / 4 / 1$ & $6725 y$ & 0.051 \\
\hline 3,10 & 3,10 & 3.81 & $u, 0 \mathrm{~s}$ & $3,8,1$ & 1.22 & $s=1,3 n$ & $=3, \sqrt{8}=$ & 0,001 \\
\hline 3.11 & 3.04 & 3.39 & -0.35 & 3.39 & 1.12 & 1.2 & 4.18 & 0.037 \\
\hline
\end{tabular}

Table 4. Calculation of planning and technical matrix

TiBuana, Vol. 04, No.1, $2021 \mid 41$ 


\section{Tibuana}

Jurnal Teknik Industri Terapan - Universitas PGRI Adi Buana

DOI : https://doi.org/10.36456/tibuana.4.01.3176.36-43

Table 5.Calculation of planning and technical matrix

\begin{tabular}{|c|c|c|c|c|c|c|c|c|c|c|c|c|c|c|c|}
\hline Contibution & 206: & 0,38 & 2061 & 1422 & 0,799 & 0,531 & 0,458 & $0,6: 1$ & $0,6$. & 1,235 & 234 & 0,345 & 2,515 & 3,152 & 0,572 \\
\hline Alondival Contibtion & 2,121 & 0,023 & 0,121 & $0,0.83$ & 0,047 & 0,031 & $Q, 27$ & 0,036 & 0,036 & 0,061 & 0,02 & 0,02 & 0,154 & 0,185 & 0,04 \\
\hline Janget & 4 & 13 & 3 & 5 & 7 & II & 2 & : & 9 & 6 & 14 & 15 & 2 & I & 10. \\
\hline
\end{tabular}

From the result of the implementation of the food safety traceability system at PT. XYZ and analysis using Quality Function Deployment method (QFD) were analyzed as follows :

1. The implementation of traceability applied at PT. XYZ is traceability level 1 or limited to internal traceability systems.

2. Documentation of food safety traceability system at PT. XYZ was carried out using paper-based traceability, this was supported by the existence of a check sheet, and also used database managementwhich was used as data backup storage and also information transfer between departments and between parties involved in the traceability system.

3. Analysis of customer satisfaction gap priorities.

The priority of customer satisfaction is obtained from the biggest negative gap value between customer satisfaction perceived with customer satisfaction expected:

a. BPOM RI information on packaging $(0,68)$.

b. The aroma of crackers isn't rancid $(0,61)$.

c. Good taste of crackers $(-0,57)$.

4. Analysis priority of importance to customer.

The customer priority is derived from the three largest values from the calculation of customer interest towards customer needs:

a. Crackers have good resistance to temperature and humidity $(3,64)$.

b. There is information about ingredients and nutritional content on the packaging $(3,55)$.

c. Crackers guaranteed hygiene $(3,50)$.

5. Analysis of Raw Weight priorities

The raw weight priority is obtained from the three largest values from the calculation of each attributes need to be repaired or developed immediately:

a. Crackers have good resistance to temperature and humidity $(5,79)$.

b. Crackers are arranged well and neatly in the packaging and and there is BPOM RI information on packaging $(5,78)$. c. Listed date expired on packaging $(5,76)$.

6. Analysis of three important priorities based on the normalized contribution value of this sequence also refers to the order of targets that have been prepared, so that the technical response is immediately realized by the company:

a. Maintain consistency with aspects of packaging according to applicable standards $(0,185)$.

b. informative product packaging $(0,154)$.

c. Maintain and make improvements to the color, taste and aroma aspects of the product $(0,12)$.

\section{CONCLUSION}

1. Food safety system at PT. XYZ refer to the Hazzard Analysis of Critical Control Points (HACCP) and SNI 01-2354-06-2006. This food safety is applied along the supply chain from delivery of raw materials to finished product delivery. Implementation of food safety system at PT. XYZ is supported by laboratory tests and the tracebility system.

2. The following parties related to traceability system at PT. XYZ:

a. Supplier: carry out the task of fulfilling the order of product raw materials (shrimp crackers) and providing information to PT. Candi Jaya Amerta such as supplier identity, type and quality of raw materials, etc.

b. PT. XYZ: in manufacturers both parts of warehouses, QA/QC, production, packaging, until distribution plays a role in storing and controlling information, databases and coding in each process flow and product.

c. Expeditor: as a third party distributing from PT. XYZ to consumers, 


\section{Tibuana}

Jurnal Teknik Industri Terapan - Universitas PGRI Adi Buana

DOI : https://doi.org/10.36456/tibuana.4.01.3176.36-43

expeditor also acts as a source of informationrelating to the distribution process. The data or information includes transportation readiness, sender's identity, proof of permit to send product, to information shipping on to the buyer.

3. Following are the recommendation points for the implementation of food safety traceability system at PT. XYZ:

a. The discipline of each employee in implementing the standard operating procedure (SOP) to support the integration of the food safety traceability system at PT. XYZ.

b. Improve activities in the process flow, especially in the production section to facilitate coding and support the integration of the food safety traceability system at PT. XYZ.

c. Improve the documentation system to support the integration of the food safety traceability system at PT. XYZ.

d. eveloping techniques for implementing food safety traceability systems that are in accordance with ISO standards and ready to face the technology-based industrial era 4.0.

4. The following are three priority technical responses that consumers are expected to realize immediately:

a. Maintain consistency of packaging aspects according to applicable standards $(0.185)$.

b. Informative product packaging (0.154). c. Maintain and make improvements to aspects of color, taste, and aroma in the product $(0.121)$.

This technical response priority is based on the results of calculating the normalized contribution and in accordance with the target sequence .

\section{REFERENCES}

1. Anatan, Lina dan Lena Ellitan. 2008. "Supply Chain Management: Teori dan Aplikasi”. Bandung: Penerbit Alfabeta. ISSN: 978-979-8433-99-3.

2. Andayani, Akbar, Sukardi dan Ani Suryani. 2015. "Desain Produk Makanan Ringan Untuk Ibu Hamil Dengan Menggunakan Quality Function Deployment (QFD)". Jurnal Agroindustri. Vol. 4, No. 1. ISSN: 2252-3324.

3. Tang, Qi, Jiajia Li, Mei Sun, dkk. 2015. "Food Traceability Systems In China: The Current Status Of AndFuture Perspectives On Food Supply Chain Databases, Legal Support,And Technological Research And Support For Food Safety Regulation". International Journal School of Public Health. Vol. 9, No. 1. 2015-01004.

4. Yuniarti, Rahmi, Wifqi Azlia, dan Ratih Ardia Sari. 2015. "Penerapan Sistem Hazard Analysis CriticalControl Point (HACCP) Pada ProsesPembuatan Keripik Tempe". Jurnal Ilmiah Teknik Industri. Vol. 14, No. 1. ISSN: 1412-6869 